\title{
First occurrence of the Asian Clam Corbicula fluminae (Bivalvia: Corbiculidae) in the Paranoá Lake, Brasília, Brazil
}

\author{
Rodrigues, JCA. ${ }^{\mathrm{a}}$, Pires-Junior, OR. ${ }^{\mathrm{b}}$, Coutinho, $M F^{\mathrm{c}}{ }^{\text {and }}$ artins-Silva, MJ. ${ }^{\mathrm{c} *}$ \\ aPós-graduação em Biologia Animal, Universidade de Brasília - UNB, CEP 70910900, Brasília, DF, Brazil \\ bLaboratório de Toxinologia, Departamento de Ciências Fisiológicas, Instituto de Ciências Biológicas, \\ Universidade de Brasília - UNB, CEP 70910-900, Brasília, DF, Brazil \\ 'Laboratório de Bentos, Departamento de Zoologia, Instituto de Ciências Biológicas, \\ Universidade de Brasília - UNB, CEP 70910-900, Brasília, DF, Brazil \\ *e-mail:mjsilva@unb.br
}

Received December 14, 2006 - Accepted January 11, 2007 - Distributed November 30, 2007

(With 2 figures)

The introduction of exotic species into an ecosystem is the second cause of biodiversity decrease (Silva and Souza, 2004). Recently, three species of Asian freshwater bivalve have been introduced into South American inland waters (Darringran, 2002): Limnoperna fortunei (Dunker, 1857); Corbicula largillierti (Philippi, 1844) and C. fluminea (Muller, 1774). Since their first report of new occurrences in South American, especially Brazil, there has been an increase. (Mansur et al., 2004).

Corbicula fluminea is native to the waters of Asia. Nowadays, this species is found in South and North America, Africa and Europe. According to McMahon (1983) and Morton (1979) this clam can cause economic and ecological impacts and it is considered as a pest species. These impacts are due to freshwater macrofouling caused by the high reproductive potential and a thrive in a wide variety of environments (Darringran, 2002).

It was believed that this species was introduced into the Rio de la Plata at the end of 1960s and beginning of the 1970s (Ituarte, 1981). Veitenheimer-Mendes (1981) recorded this species in Brazil for the first time and estimated its introduction at the beginning of the 1970s.

Paranoá Lake is an artificial reservoir that was constructed in 1959 to provide recreation activities and enhance the microclimate in Brazil's Federal Capital, Brasilia (Figure 1). The Paranoá Lake has an area of $37.5 \mathrm{~km}^{2}$ and four main creeks that provide water sources: the Bananal, Torto, Riacho Fundo and Gama (Fonseca, 2001).

Empty C. fluminea shells were discovered casually under Brageto's bridge (15 $45^{\circ}$ '49" S and $47^{\circ} 53$ ' $38^{\prime \prime} \mathrm{W}$ ) in October/2004 during observations of the Paranoá Lake's water in the Bananal branch. In this place, there were many empty shells covering the edges of the lake. Local fishermen reported that these mollusks appeared around 4-5 years ago. In this same place, empty shells of another molluscan Diplodon fontainianus (Orbigny, 1835) were found, which is a native bivalve found in the southwest of Brazil and is endangered of becoming extinct.

To observe the occupation of $C$. fluminae, the whole lake was covered and shells were collected by hand inside an area of $1 \mathrm{~m}^{2}$. In contrast to the Bananal branch
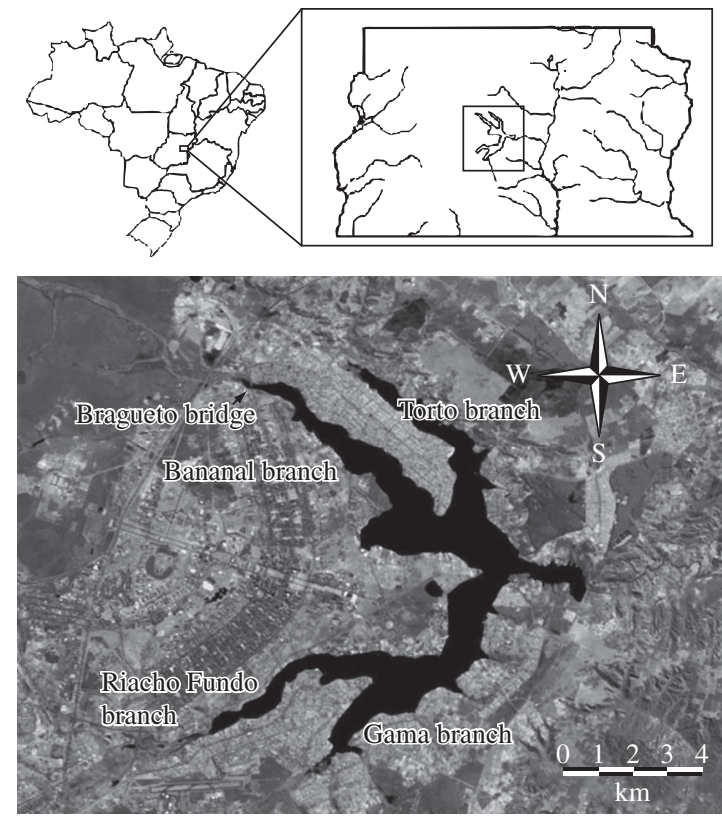

Figure 1. Paranoá Lake localization in Brazil. Assigned area means the local of Corbicula fluminea first observation.

(300 individuals $/ \mathrm{m}^{2}$ ), density was very low (3-5 individuals $/ \mathrm{m}^{2}$ ) in the Torto branch (residential area QL 7/9) and absent in other southern branches. In quick depth sampling, this bivalve was found up to $2 \mathrm{~m}$ deep.

The sampled bivalves were counted and measured with an electronic digital calipter with a precision of $0.05 \mathrm{~mm}$. An approximate age of the C. fluminea found was calculated according to Cataldo and Boltovskoy (1998). The biggest shell found was $39.63 \mathrm{~mm}$, which could represent an animal of 4-5 years, supporting fishermen's observations. Almost all the collected shells belong to the class length (20.0-25.0 mm) (Figure 2).

The early sexual maturity, high reproductive potential and a remarkable ability to occupy different environments makes this species an aggressive invasor. These characteristics can cause a drastic decline of native bivalve populations. In the Paraná and Paranapanema Rivers, Takeda et al. (2000) predicted that some native 


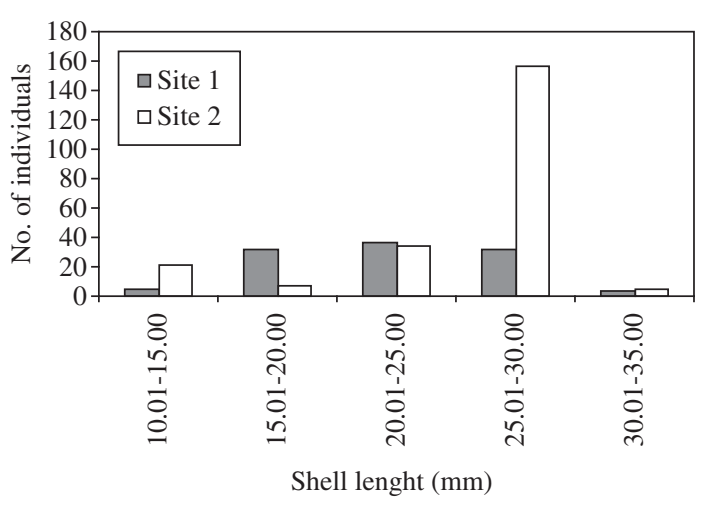

Figure 2. Relation between shell length and number of individuals of Corbicula fluminea. Site 1, Bragueto Bridge; Site 2, Residential Area QL 7/9.

mollusc populations are decreasing due to the presence of this Asian clam.

A study may be carried to analyze the real impact of this animal in communities. Corbicula's predators, such as fish and birds must be identified. Garcia and Protogino (2005) showed that seven fish species, from the Rio de la Plata, altered theirs diets to predate large amounts of invasive bivalves $C$. fluminea and L. fortunei.

There is no conclusive information concerning the origin or arrived point in Paranoá Lake, but we believe this species probably arrived at the lake from human activities as the number of pleasure boats has increased over the 5 last years.

As the Paranoá Lake is located in a planate area, a monitoring program to assess the population structure, density, distribution and control is being designed to prevent it spreading into lower river basins.

Acknowledgments - The authors would like to thank the Brasilia Fire Brigade for helping with the collection. We would like to thank Dra Maria Cristina Dreher Mansur of the Fundação Zoobotânica do Rio Grande do Sul for the species taxonomic confirmation.

\section{References}

CATALDO, D. and BOLTOVSKOY D., 1999. Population dynamics of Corbicula fluminea (Bivalvia) in the Paran'a River Delta (Argentina). Hydrobiologia, vol. 380, no. 1-3, p. 153-163.

DARRINGRAN, GA., 2002. Potential impact of filter-feeding invaders on temperate inland freshwater environments. Biological invasions, vol. 4, no. 1-2, p. 145-156.

FONSECA, FO., 2001. Olhares sobre o Lago Paranoá. $1^{\text {a }}$ Edição, Secretaria de Meio Ambiente e Recursos Hídricos, Brasília, DF, 425p.

GARCIA, ML. and PROTOGINO, LC., 2005. Invasive freshwater molluscs are consumed by native fishes in South America. J. Appl. Ichthyol., vol. 21, no. 1, p. 34-38

ITUARTE, CF., 1981. Primera noticia acerca de la presencia de pelecípodos asiáticos em el área rioplatense. Neotropica, vol. 27 , no. 7 , p. $79-82$.

MANSUR, MCD., CALLIL, CT., CARDOSO, FF. and IBARRA, JAA., 2004. Uma retrospectiva e mapeamento da invasão de espécies de Corbicula (Mollusca, Bivalvia, Veneroida, Corbiculidae) oriundas do sudeste asiático, na América do Sul. In Silva, JSV. and Souza, RCCL. Água de lastro e bioinvasão. Rio de Janeiro: Interciência p. 39-58.

McMAHON, RF., 1983. Ecology of na invasive pest bivalve Corbicula. In Russell-Hunter, WD. The Mollusca Ecology. Academic Press Inc, New York. p. 505-561.

MORTON, B., 1979. Freshwater fouling bivalves. In BRITON, JC. Proc. First Internatiinal Corbicula Symposium Texas Christian University. Fort Worth. p. 13-15.

TAKEDA, AM., HIGUTI, J., FUJITA, DS., and BUBENA, MR., 2000. Proliferação de uma espécie de bivalve invasora, Corbicula fluminae, na área alagável do Alto Paraná (Brasil). In Seminário Brasileiro sobre água de lastro, 1, Arrail do Cabo, p.11.

VEITENHEIMER-MENDES, I., 1981. Corbicula manilensis, (Philippi, 1844) molusco asiático, na bacia do Jacuí e do Guaíba, Rio Grande do Sul, Brasil (Bivalvia, Corbiculidae). Iheringia Série Zoologia, vol. 70, no. 60, p. 63-74.

SILVA, JSV and SOUZA, RCCL., 2004. Água de lastro e bioinvasão - Rio de Janeiro: Interciência 224p. 